\title{
S960QL Yapı Çeliğinin İşlenebilirliğinin Sonlu Elemanlar Yöntemi ile İncelenmesi
}

\author{
Rüstem Binali ${ }^{*}$, Süleyman Yaldız ${ }^{2}$, Süleyman Neşeli ${ }^{3}$ \\ ${ }^{1 *}$ Selçuk Üniversitesi, Teknoloji Fakültesi, Makine Mühendisliği Bölümü, Konya, Türkiye, (ORCID: 0000-0003-0775-3817), rustem.binali@ selcuk.edu.tr \\ ${ }^{2}$ Selçuk Üniversitesi, Teknoloji Fakültesi, Makine Mühendisliği Bölümü, Konya, Türkiye (ORCID: 0000-0003-0931-9643), syaldiz@ selcuk.edu.tr \\ ${ }^{3}$ Selçuk Üniversitesi, Teknoloji Fakültesi, Makine Mühendisliği Bölümü, Konya, Türkiye (ORCID: 0000-0003-1553-581X), sneseli@ selcuk.edu.tr
}

(İlk Geliş Tarihi 16 Eylül 2021 ve Kabul Tarihi 21 Kasım 2021)

(DOI: 10.31590/ejosat.996324)

ATIF/REFERENCE: Binali, R., Yaldız, S. \& Neşeli, S. (2021). S960QL Yapı Çeliğinin İşlenebilirliğinin Sonlu Elemanlar Yöntemi ile İncelenmesi. Avrupa Bilim ve Teknoloji Dergisi, (31), 85-91.

\section{$\ddot{O} \mathbf{z}$}

Talaşlı üretim işlemlerinde frezeleme operasyonları yaygın olarak kullanılmaktadır. Frezeleme işlemi çok ağızlı kesici takımlarla yapılması nedeniyle farklı kesme mekaniğine sahiptir. Talaşlı imalatta kesme mekaniği işleme verimini belirleyen birçok işlem çıktılarına (kesme kuvveti, pürüzlülük, takım ömrü vb.) etki etmektedir. Bu nedenle işlem sırasında oluşan her bir çıktıya etki eden parametrelerin araştırılması gereklidir. Fakat bu işlemler oldukça maliyetli olup zaman almaktadır. Bu kapsamda sonlu elemanlar yönteminin kullanılmasıyla yapılan işleme simülasyonları vasıtasıyla elde edilen işlem çıktıları, fiziksel çalışmalarda elde edilen değerlerin tahminini yaparak pek çok avantaj sunmaktadır. Çalışmada S960QL yapı çeliği malzemesinin işlenebilirliği sonlu elemanlar yönteminde incelenmiştir. Frezeleme işlemleri üç farklı yanal derinlik $(0.8,1.2,1.6 \mathrm{~mm})$, üç farklı eksenel derinlik $(4,6,8$ $\mathrm{mm})$, üç farklı kesme hızı $(180,200,220 \mathrm{~m} / \mathrm{dak})$ ve üç farklı ilerleme miktarında $(0.08,0.12,0.16 \mathrm{~mm} / \mathrm{diş})$ yapılmıştır. Analiz neticesinde kesme kuvvetleri, moment ve sıcaklık değerleri incelenmiştir. Yapılan çalışmanın sonucunda değerlendirilen işlem çıktılarına göre sonlu elemanlar yönteminin talaşlı imalatta işlenebilirlik deneyleri için kullanılabilir olduğu belirlenmiştir.

Anahtar Kelimeler: Frezeleme, Sonlu elemanlar, İşlenebilirlik, Yapı çeliği.

\section{An Investigation of Machinability of S960QL Structural Steel by Finite Element Method}

\begin{abstract}
Milling operations are widely used in machining operations. The milling process is done with multi-edged cutting tools and so it has different cutting mechanics. In machining, cutting mechanics affects many process outputs (cutting force, roughness, tool life, etc.) that determine the machining efficiency. For this reason, it is necessary to investigate the parameters that affect each output that occurs during the process. However, these processes are very costly and the take time. In this context, the process outputs obtained through machining simulations using the finite element method offer many advantages by estimating the values obtained in physical studies. In this study, the machinability of S960QL structural steel material was investigated using the finite element method. Milling operations are performed at three different lateral depths $(0.8,1.2,1.6 \mathrm{~mm})$, three different axial depths $(4,6,8 \mathrm{~mm})$, three different cutting speeds $(180,200,220 \mathrm{~m} / \mathrm{min})$ and three different feed rates $(0.08,0.12,0.16 \mathrm{~mm} / \mathrm{tooth})$. As a result of the analysis, shear forces, moment and temperature values were examined. As a result of the study, it was determined that the finite element method can be used for machinability tests in machining according to the evaluated process outputs.
\end{abstract}

Keywords: Milling, Finite elements, Machinability, Structural steel.

*Sorumlu Yazar: rustem.binali@ selcuk.edu.tr 


\section{Giriş}

İmalat sektöründe teknoloji ile birlikte artan rekabet günümüzde üretimin en iyi şekilde oluşturulmasını zorunlu kılmıştır. Üreticiler ve ürünlerinden istenilen yalnızca uygun maliyet değil aynı zamanda en yüksek kalite ve kısa sürede üretimdir. Günümüzde geliştirilmiş olan modern imalat yöntemleri ile üretilen ürünler beklentilerin bir kısmını karşılayabilmektedir. Ancak müşteriler tarafından istenilen kriterler tam anlamıyla karşılanamamaktadır. Bu nedenle modern imalat yöntemlerine ek olarak müşterilerin beklentilerinin karşılanabilmesi için geleneksel imalat yöntemlerinin optimizasyonunu yapmak ve teknoloji tabanlı işlemler yapılmasını gerektirmektedir. Geleneksel imalat yöntemlerinden talaşlı imalat yöntemleri ise ürün işlenmesinde en yaygın kullanılan yöntemlerdendir. Talaşlı imalat yöntemleri, frezeleme, tornalama, delme ve diş açma gibi işlemleri kapsamaktadır (Binali, 2017; Korkmaz vd., 2018).

Talaşlı imalat yöntemlerinin arasında ise frezeleme yöntemi yaygın olarak kullanılmaktadır. Ancak bu yöntemde kesme mekaniği diğer talaşlı imalat yöntemlerine göre farklıdır. Kesme mekaniğinin farklı olması, frezeleme yönteminde kesme işleminin hem aynı anda birden fazla yönde gerçekleşmesinden hem de çok ağızlı kesici takım kullanılmasından kaynaklanmaktadır. Bu nedenle kesme işlemi sırasında meydana gelebilecek hataların en aza indirilebilmesi için kesme parametrelerinin iyileştirilmesi oldukça önemlidir. Frezeleme işlemini oluşturan esas parametreler ise kesme hızı, diş başına ilerleme miktarı ve kesme derinliğidir. Son yıllarda kesme parametrelerinin iyileştirilebilmesinin sağlanabilmesi için fiziksel deneyler yerine sonlu elemanlar yöntemi yaygın olarak kullanılmaktadır. Bu yöntem ile yapılan iyileştirme işlemlerinde işlem sırasında meydana gelen kesme kuvveti, moment ve sıcaklık gibi neticeler elde edilebilmektedir. $\mathrm{Bu}$ kapsamda frezeleme işlemiyle alakalı yapılan çalışmalarda, istenilen yüzey kalitesine ulaşmak maksadıyla iş parçası malzemesi ve kesici takım malzemesi için gerekli olan işleme parametreleri ve seviyeleri belirlenerek işleme maliyetlerinin minimum seviyede olması hedeflenmektedir.

Araştırmalar neticesinde literatürde sonlu elemanlar yöntemi ile gerçekleştirilen pek çok çalışmanın olduğu görülmektedir. Bu çalışmaların bazıları şu şekilde özetlenmiştir; Ceretti ve arkadaşları, ISO $2017 \mathrm{AlCuMgPb}$ alüminyum alaşımına gerçekleştirdikleri tornalama deneyleri ve sonlu elemanlar yöntemi ile elde edilen sonuçları kıyaslamışlardır. Çalışmaları sonucunda malzemenin seçimi, kesici takımların tasarlanması ve işleme parametrelerin optimizasyonu için sonlu elemanlar yönteminin kullanılabilir olduğunu belirtmişlerdir (Ceretti vd., 2000). Gao ve arkadaşları, SUS 321 paslanmaz çeliğinin delinmesinde kesme parametrelerinin etkilerini sonlu elemanlar yöntemine bağlı olarak araştırmışlardır. Delme simülasyonunun neticelerine bağlı olarak matkap çapı ve ilerleme miktarının kesme hızına göre moment ve ilerleme kuvvetinin üzerinde daha etkin parametreler olduğunu belirlemişlerdir. Bunun yanı sıra, en yüksek sıcaklık değerinin takım-talaş arayüzeyinde meydana geldiğini ve kesici takım aşınmasının tahmin edilebileceğini belirmişlerdir (Gao vd., 2011). Özel, AISI 4340 malzemesinde değişken geometrilere sahip PCBN kesici takımlar ile fiziksel deneyler ve tornalama simülasyonu işlemlerinde talaş geometrisi, kesme kuvveti ve takım aşınmalarını incelemiştir. Çalışması sonucunda kesme kuvveti bakımından fiziksel deneyler ve SEY simülasyonu sonuçlarının birbirlerine benzediğini belirtmiştir (Özel, 2009). Yang ve Sun, delik delme işlemi için bir SEY geliştirmiştir. Çalışmalarında iş parçası malzemesi olarak titanyum alaşımı olan Ti6Al4V malzemesini ve kesici takım malzemesi olarak da kaplanmamış karbür kullandıklarını belirtmişlerdir. Elde ettikleri sonuçlara göre kesme kuvvetinin deneysel değerlerle, sonlu elemanlar yöntemiyle elde edilen değerlerin karşılaştırılması sonucunda sonlu elemanlar yönteminin bu işlem için uygun olduğunu belirlemişlerdir. Ayrıca sonlu eleman modelinin, optimum delme parametrelerini seçmek ve kesici takım tasarımının geliştirilmesi için kullanılabileceğini, uzun ve pahalı fiziksel deney sürecinden kaçınılabileceğini belirtmişlerdir (Yang ve Sun, 2009). Kurt ve arkadaşları, AISI H13 malzemesinin seramik kesici takımlar ile sert tornalanması sırasında kesici takım gerilmelerini belirlemek için sonlu elemanlar modeli geliştirmişlerdir. Çalışmaları sonucunda SEY'deki gerilim konsantrasyonu alanlarının takım aşınması tipi hakkında bilgi verdiğini vurgulamışlardır (Kurt vd., 2015). Bir diğer çalışmada, Gök ve arkadaşları, AISI 4140 malzemesinin fiziksel ve sonlu elemanlar yönteminde delme işlemini gerçekleştirmişlerdir. Farklı helis açılarına sahip kesici takımlar kullanarak ilerleme ve kesme hızlarının işlem sırasında oluşan kesme kuvvetlerini ve momentleri değerlendirmişlerdir (Gök vd., 2013). Özçelik ve Bağc1, Al7075-T651 ve AISI 1040 malzemelerine TiAlN kaplamaya sahip helisel matkap kesici takımlarıyla delme işlemleri uygulayarak, malzemelerin üzerinde işlem sırasında meydana gelen sıcaklıkları deneysel ve sonlu elemanlar yöntemini kullanarak incelemişlerdir. İlerleme miktarındaki artış ile sıcaklık değerinin önemli düzeyde arttığını ve Lagrange koduna dayalı SEY'e göre yapılan analizlerle kuru şartlar altında yapılan fiziksel deney sonuçları arasında iyi bir benzerlik olduğunu vurgulamışlardır (Özçelik ve Bağcı, 2006). Yan ve arkadaşları, AISI H13 takım çeliğinin sert tornalanması sırasında gerinim, gerinim oranı ve sıcaklığın akış gerilimi üzerindeki etkilerini araştırmışlardır. Sert tornalamada akış gerilmelerinin mekanik davranışlarının belirlenmesinin çok zor olduğu ve bu problemin sonlu elemanlar yöntemi ile çözülmesi gerektiğini iddia etmektedirler. Sonuç olarak fiziksel deney verileri ile sonlu elemanlar verileri kıyaslandığında SEY modelinin kullanılabilir olduğunu berlitmişlerdir (Yan vd., 2007). Kormaz ve arkadaşları, AISI 420 Martenzitik paslanmaz çeliğinin delinebilirliğini SEY ile analiz etmişlerdir. Çalışmaları sonucunda delme işlemi için gerekli parametrelerin optimizasyonu için SEY'in kullanılabilir bir araç olduğunu vurgulamışlardır (Korkmaz vd., 2018).

Literatür çalışmasının değelendirilmesi sonucunda, S960QL yapı çeliğinin frezelenebilirliği üzerine kapsamlı bir çalışmanın olmadığı tespit edilmiştir. Bu çalışmada S960QL yap1 çeliğinin sonlu elemanlar yöntemi ile frezeleme simülasyonlarında, yanal derinliğin, eksenel derinliğin, diş başına ilerleme miktarının ve kesme hızı parametrelerinin kesme kuvveti, moment ve sıcaklık üzerindeki etkileri analiz edilerek frezenelenbilirliği incelenmiştir.

\section{Materyal ve Metot}

Yapılan sonlu elemanlar çalışması için iş parçası malzemesi olarak endüstride kullanılan S960QL yapı çeliği malzemesi kullanılmıştır. Kullanılan malzemenin frezelenebilirliği sonlu elemanlar yöntemine bağlı olarak frezeleme simülasyonları değerlendirilmiştir. S960QL yapı çeliği malzemesinin kimyasal 
bileşimi ve mekaniksel özellikleri Tablo 1 ve Tablo 2'de verilmiştir.

Tablo 1. S960QL malzemesinin kimyasal bileşimi (SSAB, 2021).

\begin{tabular}{|c|c|c|c|c|}
\hline $\mathrm{C}$ & $\mathrm{Si}$ & $\mathrm{Mn}$ & $\mathrm{P}$ & $\mathrm{S}$ \\
\hline 0,20 & 0,50 & 1,60 & 0,020 & 0,010 \\
\hline $\mathrm{Cr}$ & $\mathrm{Cu}$ & $\mathrm{Ni}$ & $\mathrm{Mo}$ & $\mathrm{B}$ \\
\hline 0,80 & 0,3 & 2,0 & 0,70 & 0,005 \\
\hline
\end{tabular}

Tablo 2. S960QL malzemesinin mekaniksel özellikleri (SSAB, 2021).

\begin{tabular}{|l|c|}
\hline Minimum Akma dayanımı $\mathrm{R}_{\mathrm{p} 0.2}(\mathrm{MPa})$ & 960 \\
\hline Minimum Çekme dayanımı $\mathrm{R}_{\mathrm{m}}(\mathrm{MPa})$ & $980-1150$ \\
\hline Germe $\mathrm{A}_{5}(\min \%)$ & 12 \\
\hline
\end{tabular}

S960QL malzemesinin sonlu elemanlar yöntemi için gerekli olan Johnson-Cook (JC) model parametreleri, Cadoni ve Forni tarafindan tanımlandığı göz önüne alınmıştır (Tablo 3). JohnsonCook malzeme modeli eşitliği aşağıda verilmiştir (Korkmaz vd., 2018).

$\sigma^{0}=\left(\mathrm{A}+\mathrm{B}\left(\varepsilon^{\mathrm{p}}\right)\right)^{\mathrm{n}}\left(1+\mathrm{C} \ln \left(\frac{\dot{\varepsilon}^{\mathrm{p}}}{\dot{\varepsilon}_{0}}\right)\right)\left(1-(\widehat{\mathrm{T}})^{\mathrm{m}}\right)$

Denklem 1'deki A, B, C, n ve m olan mekanik testlerin kullanılmasıyla bulunan malzemenin parametreleri sırası ile oda sıcaklığındaki akma gerilmesini, gerinim sertleşmesini, gerinim hızının sabitini, deformasyon sertleşmesinin üssü ve deformasyon hızının duyarlılığının üssüdür. Denklemdeki diğer parametreler ise $\varepsilon_{p}, \dot{\varepsilon}, \dot{\varepsilon}_{0}, \mathrm{~T}_{\mathrm{r}}, \mathrm{T}_{\mathrm{m}}$ ve $\mathrm{T}$, sırası ile eşdeğer plastik gerinim, plastik gerinmenin oranı, referans gerinimin oranı, oda sicaklığı, malzemenin erime sicaklığı ve referans sıcaklığıdır. Belirtilen $\dot{\varepsilon}_{0}$ ve $C$ genelde referans sıcaklığında ve/veya altında ölçümü yapılan değerlerdir.

Tablo 3. S960QL malzemesinin JC model parametreleri (Cadoni ve Forni, 2019).

\begin{tabular}{|c|c|}
\hline $\mathrm{A}(\mathrm{MPa})$ & 1034 \\
\hline $\mathrm{B}(\mathrm{MPa})$ & 828 \\
\hline $\mathrm{n}$ & 0,6539 \\
\hline $\mathrm{c}$ & 0,015045 \\
\hline $\mathrm{m}\left(400^{\circ} \mathrm{C}\right)$ & 1,028 \\
\hline $\mathrm{m}\left(550^{\circ} \mathrm{C}\right)$ & 1,277 \\
\hline $\mathrm{m}$ (ortalama) & 1,154 \\
\hline
\end{tabular}

Frezeleme işlemleri sonlu elemanlar programı kullanılarak yapılmıştır. $\mathrm{Bu}$ kapsamda frezeleme işleminde kullanılan S960QL malzemesinin uzunluğu $50 \mathrm{~mm}$, genişliği $50 \mathrm{~mm}$ ve kalınlığ $10 \mathrm{~mm}$ olarak programa tanımlanması yapılmıştır. Kesici takım malzemesi olarak P kalitesinde TiAlN kaplamalı iki ağızlı karbür freze takımı tanımlanmıştır. S960QL malzemesi için KENNAMETAL firması tarafindan tavsiye edilen EDCT 10T308PDERLD KC725M kalitesinde kesici takım kullanılmıştır. Kesici takımın sonlu elemanlar programında kullanılabilmesi için üç boyutlu taraması yapılarak CATIA programında modellemesi yapılmıştır. Kesici takım 0,8 köşe radyusuna, 3,75 $\mathrm{mm}$ kalınlığa, 12,05 $\mathrm{mm}$ kesme kenarı uzunluğuna ve 150 yaklaşma açısına sahiptir. Kesici takım ve iş parçası malzemeleri arasında yüzey ilişsi Coulomb modeli kullanılarak yapılmış olup sürtünme katsayısı 0,5 olarak seçilmiştir. Simülasyon işlemlerinde köşe frezeleme (cutting edge) ve aynı yönlü frezeleme seçilmiştir. Frezeleme simülasyonlarına tanımlanan sonlu elemanların model görünümü ve kesici takımın geometrik şekli Şekil 1'de verilmiştir.

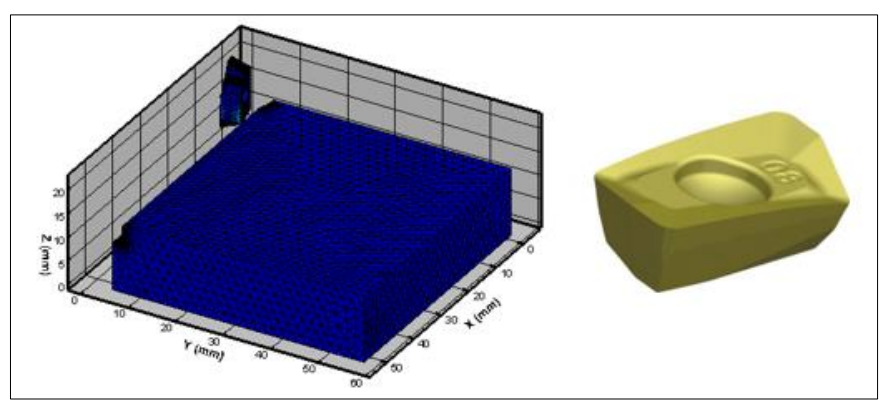

Şekil 1. Kesici takım geometrisi ve sonlu elemanlar modeli.

Kesme parametreleri olarak, yanal derinlik, eksenel derinlik, kesme hızı ve diş başına ilerleme miktarı seçilmiştir. Bu parametreler literatürde yer alan yapı çelikleri için seçilen parametreler ve KENNAMETAL firması tarafindan önerilen parametrelerin değerlendirilmesi ile belirlenmiştir. Kullanılan parametreler ve değerleri Tablo 4 'te verilmiştir.

Tablo 4. Çalışmada kullanılan kesme parametreleri.

\begin{tabular}{|c|c|c|c|c|}
\hline $\begin{array}{c}\text { Deney } \\
\text { No }\end{array}$ & $\begin{array}{c}\text { Yanal } \\
\text { derinlik } \\
\text { (mm) }\end{array}$ & $\begin{array}{c}\text { Eksenel } \\
\text { Derinlik } \\
\text { (mm) }\end{array}$ & $\begin{array}{c}\text { Kesme } \\
\text { Hızı } \\
\text { (m/dak) }\end{array}$ & $\begin{array}{c}\text { Ilerleme } \\
\text { miktarı } \\
\text { (mm/diş) }\end{array}$ \\
\hline 1 & 0,8 & 4 & 180 & 0,08 \\
\hline 2 & 0,8 & 6 & 200 & 0,12 \\
\hline 3 & 0,8 & 8 & 220 & 0,16 \\
\hline 4 & 1,2 & 4 & 200 & 0,16 \\
\hline 5 & 1,2 & 6 & 220 & 0,08 \\
\hline 6 & 1,2 & 8 & 180 & 0,12 \\
\hline 7 & 1,6 & 4 & 220 & 0,12 \\
\hline 8 & 1,6 & 6 & 180 & 0,16 \\
\hline 9 & 1,6 & 8 & 200 & 0,08 \\
\hline
\end{tabular}

Tablo 4'te yer alan kesme parametrelerinin kullanılması ile sonlu elemanlar yöntemindeki simülasyonlar sonucunda işlem sırasında meydana gelen kesme kuvveti, moment ve sicaklık değerlerine göre S960QL yap1 çeliğinin frezelenebilirliği incelenmiştir.

\section{Sonuçların Değerlendirilmesi}

Çalışmada, sonlu elemanlar yöntemi ile frezeleme işlemini etkileyen esas kesme parametrelerinin (diş başına ilerleme miktarı, kesme derinlikleri ve kesme hızı) işlem esnasında meydana gelen kesme kuvvetleri $\left(F_{x}, F_{y}\right.$ ve $\left.F_{z}\right)$, moment $\left(M_{z}\right)$ ve kesici takım üzerindeki sıcaklık (T) üzerindeki etkileri incelenmiştir. Sonlu elemanlar yönteminin analizi sonuçlarına göre değerlendirmeler detaylı olarak alt başlıklarda verilmiştir. 


\subsection{Kesme Kuvveti Değerlendirilmesi}

Frezeleme simülasyonları sonucunda meydana gelen kesme kuvvetleri (Fx, Fy ve Fz) değerleri ilerleme miktarı-kesme hızına, eksenel derinlik-kesme hızına ve yanal derinlik-kesme hızına bağlı olarak değişimleri Şekil 2, Şekil 3 ve Şekil 4'te verilmiştir.

Genel anlamda eksenel derinlik miktarı ve kesme hızlarına göre kesme kuvvetlerinde artış meydana gelmektedir. Ayrıca sabit kesme hızında eksenel derinliğin artması ile ilerleme yönündeki $\left(\mathrm{F}_{\mathrm{x}}\right)$ kesme kuvvetinde de artış gözlenmiştir. Aynı şekilde yanal derinliğe ve ilerleme miktarına göre inceleme yapıldığında, artış ile beraber kesme kuvvetlerinde de artış oluştuğu gözlenmiştir. Ancak bazı değerlerde sabit kesme hızında artan ilerleme miktarı, yanal derinlik ya da eksenel derinlikte kesme kuvvetinde azalış meydana geldiği gözlenmektedir. $\mathrm{Bu}$ durumun kesici takım ile belirlenen iş parçası malzemesinin kesilmesinde gerekli olan optimum parametreden kaynaklandığı düşünülmektedir. Ayrıca meydana gelen artışların nedeni artan talaş kesit alanının ve bu nedenle birim zamanda malzemeden kaldırılan talaşın miktarı için gerekli olan gücün artmasına atfedilebilir (Korkmaz vd., 2018; Küçüktürk, 2013). Bu durum ayrıca işlem sırasında artan sıcaklık ile iş parçası malzemesinin dayanımında azalma oluştuğu göz önüne alınarak açıklanabilir.

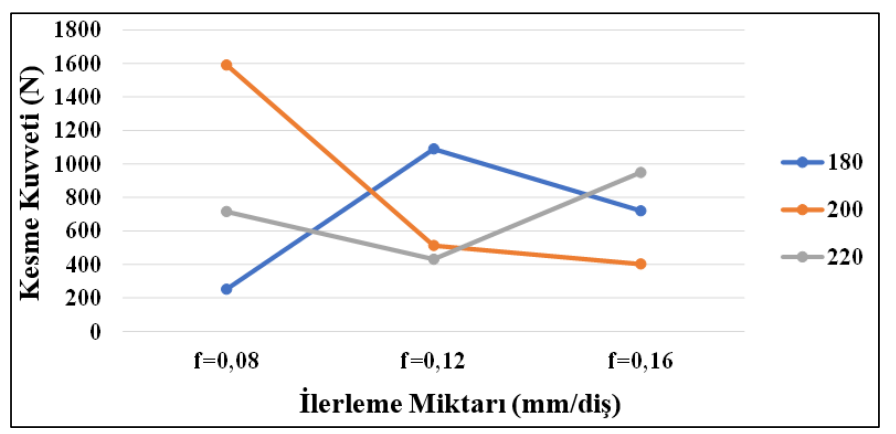

(a)

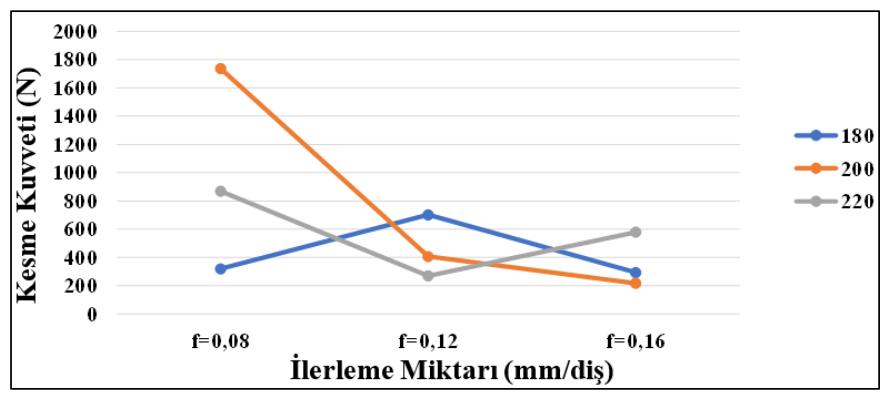

(b)

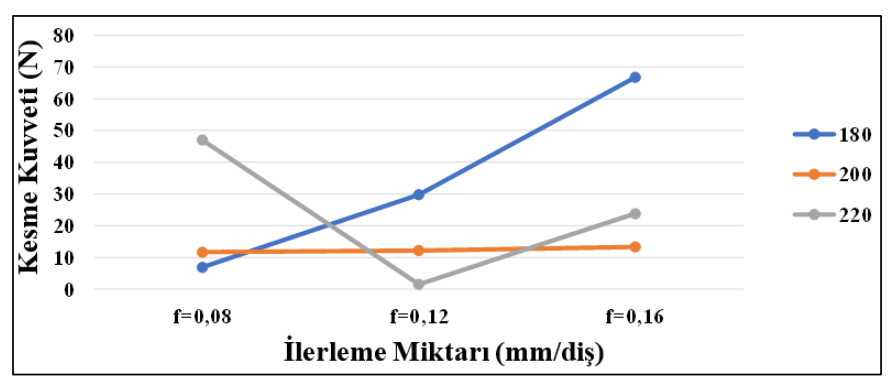

(c)

Şekil 2. Ilerleme miktarl ve kesme hızına bağlı kesme kuvveti değişimleri a) $F_{x} b$ ) $F_{y} c$ ) $F_{z}$
İlerleme miktarı ve kesme hızına bağlı grafiklerin incelenmesi sonucunda genel anlamda ilerleme miktarının artması ile kesme kuvvetlerinde düşüş meydana gelmektedir. Ancak kesme hızlarına göre değerlendirildiğinde kesme hızlarının artışıyla ilerleme ve yanal kuvvet değerlerinde kesme kuvvetinin arttığı ve bir süre sonra düştüğü görülmektedir. Literatür incelendiğinde ilerleme kuvvetinin artması kesme kuvvetini arttırmakta ve kesme hızının artması kesme kuvvetini azaltmaktadır (Yardımeden ve Turan, 2015; Tekaüt, 2008; Chinchanikar ve Choudhury, 2013). Ancak genel anlamda bu ifadeler literatürde tornalama ve delme için kullanılmaktadır. Frezeleme kesme mekaniği işleminin farklı olması nedeniyle dalgalanmalı sonuçlar meydana gelebilmektedir (Binali, 2017). Şekil 2'ye göre ilerleme yönünde meydana gelen en yüksek kesme kuvveti $(1589,93 \mathrm{~N})$ 0,08 mm/diş ilerleme miktarı ve 200 $\mathrm{m} /$ dak kesme hızında oluşmuştur. İlerleme yönündeki en düşük kuvvet $(252,57 \mathrm{~N})$ değeri ise $0,08 \mathrm{~mm} /$ diş ilerleme miktarında ve $180 \mathrm{~m} /$ dak kesme hızında oluşmuştur. İlerleme yönündeki en düşük ve en yüksek kuvvetler arasında \%530’luk bir değişim oluşmuştur. Yanal kuvvet değerlerinde ise en yüksek kuvvet $(1736,83 \mathrm{~N})$ değeri $0,08 \mathrm{~mm} /$ diş ilerleme miktarı ve $200 \mathrm{~m} / \mathrm{dak}$ kesme hızında oluşmuştur. En düşük kuvvet $(216,895 \mathrm{~N})$ değeri ise $0,16 \mathrm{~mm} /$ diş ilerleme miktarı ve $200 \mathrm{~m} /$ dak kesme hızında meydana gelmiştir. Yanal kesme kuvvetlerinin en düşük ve en yüksek değerleri arasında \%701'lik bir değişim meydana gelmiştir.

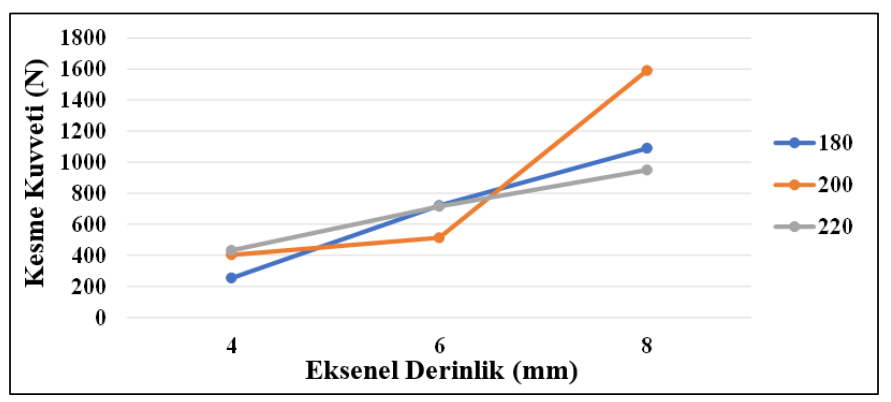

(a)

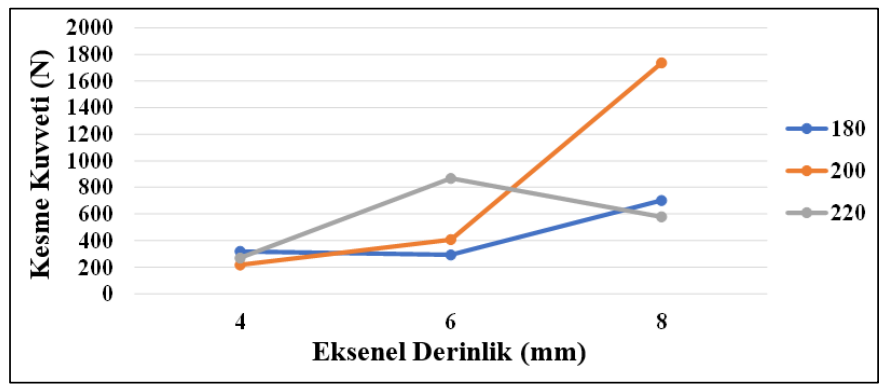

(b)

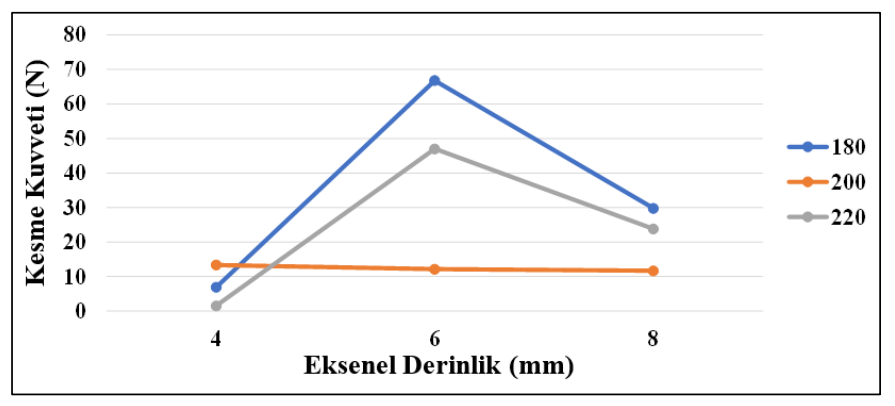

(c)

Şekil 3. Eksenel derinlik ve kesme hızına bağlı kesme kuvveti değişimleri a) $F_{x} b$ ) $F_{y} c$ ) $F_{z}$ 
Şekil 3 'te yer alan eksenel derinlik ve kesme hızına bağlı kesme kuvvetleri grafiğinin incelenmesi ile eksenel derinliğin artması ile kesme kuvveti artmaktadır. Bu durum derinliğin ve meydana gelen titreşimin artmasıyla kesme kuvvetinin artmasına atfedilebilir. Eksenel derinliğin yani kesme derinliğinin artması ile kesme kuvvetinde meydana gelen artış literatür ile uyum içerisindedir (Günay vd., 2017). Eksenel derinliğe ve kesme hızına bağlı olarak hem ilerleme yönünde hem de yanal kuvvet olarak meydana gelen en yüksek kesme kuvveti değeri $8 \mathrm{~mm}$ derinlikte ve en düşük kesme kuvveti değeri ise $4 \mathrm{~mm}$ derinlikte meydana gelmiştir. $\mathrm{Bu}$ beklenilen bir durum olup sonlu elemanlar yönteminin doğru bir simülasyon gerçekleştirdiğini göstermektedir.

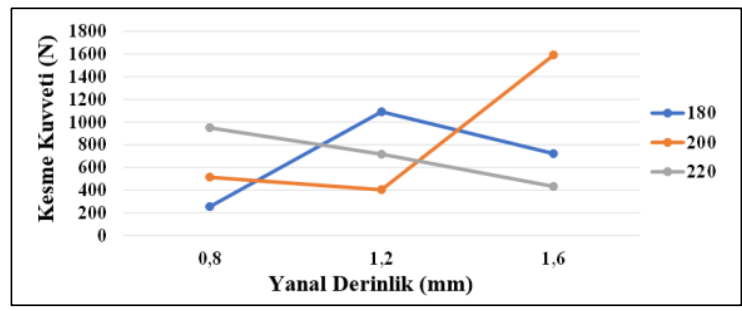

(a)

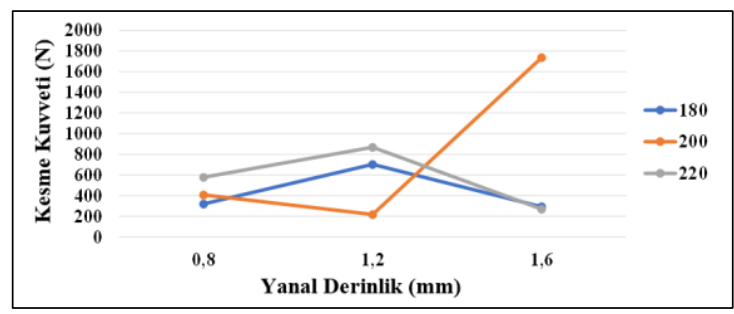

(b)

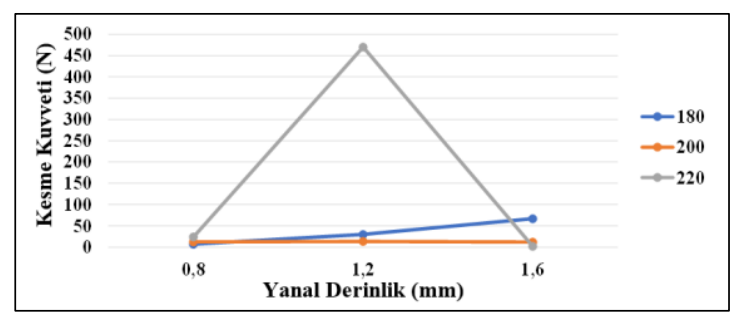

(c)

Şekil 4. Yanal derinlik ve kesme hızına bağll kesme kuvveti değişimleri a) $F_{x} b$ ) $F_{y} c$ ) $F_{z}$

Yanal derinlik ve kesme hızına bağlı kesme kuvveti değişimlerinin grafiklerinin incelemesi sonucunda yanal derinliğin artması ile kesme kuvvetlerinde artış meydana gelmiş̧ir. Bu durum aynı eksenel durumda olduğu gibi titreşime bağlı olarak kesme kuvvetinde artış meydana gelmesi ile açıklanabilir. Hem kesme hızının arttıılması hem de yanal derinliğin arttırılmasıyla kesme kuvvetlerinde artış meydana gelmektedir. Ancak yanal derinliğin sabit kesme hızının arttırılması sonucunda bir süre artış sonrasında kesme kuvvetlerinde düşüş meydana gelmektedir. Yanal derinlik ve kesme hızına bağlı olarak oluşan en yüksek kesme kuvveti değişimi \%493 ile 1,6 mm yanal kesme derinliğinde kesme hızının $180 \mathrm{~m} /$ dak'dan $200 \mathrm{~m} /$ dak'ya arttırıldığında yanal kuvvette $\left(\mathrm{F}_{\mathrm{y}}\right)$ meydana gelmiştir. En düşük değişim ise $\% 9$ olarak yine $1,6 \mathrm{~mm}$ yanal derinlikte ve kesme hızını 180 $\mathrm{m} /$ dak'dan $220 \mathrm{~m} /$ dak'ya artması sonucunda yanal kuvvette $\left(\mathrm{F}_{\mathrm{y}}\right)$ meydana gelmişsir.
Şekil 2, Şekil 3 ve Şekil 4'teki grafiklerin genel olarak değerlendirilmesi sonucunda meydana gelen $F_{x}$ kuvvetleri 252,57-1589,93 N arasında değişmektedir. En düşük ve en yüksek kuvvet arasında \%530'luk bir değişim söz konusudur. $\mathrm{F}_{\mathrm{y}}$ kuvvetlerinde ise $216,895-1736,83 \mathrm{~N}$ arasinda ve \%701'lik değişim meydana gelmiştir. $F_{z}$ kuvvetlerinde ise 1,53155$66,7766 \mathrm{~N}$ ve $\% 4260$ 'llk bir değişim meydana gelmiştir. İlerleme yönündeki en düşük kuvvet $(252,57 \mathrm{~N}) 0,8 \mathrm{~mm}$ yanal derinlik, $4 \mathrm{~mm}$ eksenel derinlik $180 \mathrm{~m} /$ dak kesme hızı ve 0,08 $\mathrm{mm} /$ diş ilerleme miktarında meydana gelmiştir. En yüksek kuvvet $(1589,93 \mathrm{~N})$ ise $1,6 \mathrm{~mm}$ yanal derinlik, $8 \mathrm{~mm}$ eksenel derinlik $200 \mathrm{~m} /$ dak kesme hızı ve $0,08 \mathrm{~mm} /$ diş ilerleme miktarında meydana gelmiştir. Elde edilen sayısal verilere göre kesme kuvvetine etki eden en önemli parametrelerin ilerleme miktarı ve yanal derinliğin olduğu sonucuna varılmıştır.

\subsection{Moment Değerlendirilmesi}

Yapı çeliğinin frezelenmesi esnasında meydana gelen moment değerlerinin $\left(\mathrm{M}_{\mathrm{z}}\right)$ işleme parametrelerine göre değişim grafikleri Şekil 5, Şekil 6 ve Şekil 7'de verilmiştir. Moment değerleri incelendiğinde genel olarak kesme kuvvetlerinin artması ile moment değerlerinde de artış meydana gelmiştir. Ayrıca en çok etki eden parametrenin eksenel derinlik olduğu tespit edilmiştir.

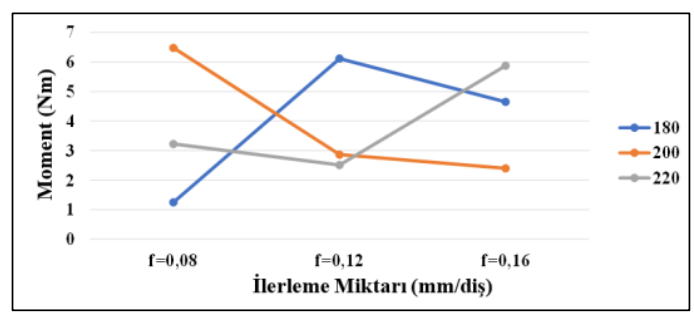

Şekil 5. İlerleme miktarına ve kesme hızına bağll olarak moment grafiği.

Şekil 5'e göre değerlendirilme yapıldığında, genel anlamda ilerleme miktarına bağlı olarak moment değerlerinde düşüş meydana gelmektedir. Literatürde bulunan sonlu elemanlar çalışmalarına göre ilerleme miktarına bağlı olarak talaş kesit alanındaki artış ve bu nedenle talaş kaldırmak için gerekli kuvvetin artması sonucunda moment miktarında da artış olması beklenmektedir (Korkmaz vd., 2018; Gökçe vd., 2017). Frezeleme simülasyonları sonucunda en yüksek ve en düşük $M_{z}$ değerleri arasında \%418'lik bir değişim olduğu tespit edilmiştir.

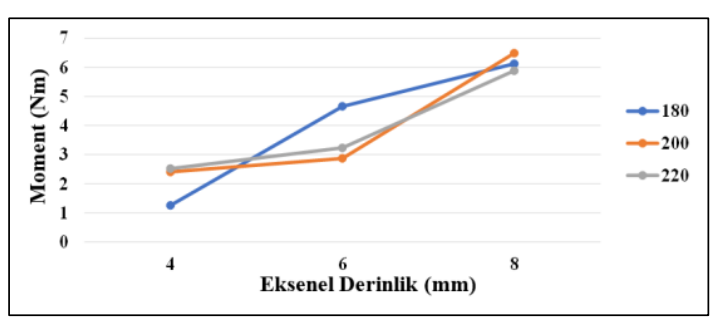

Şekil 6. Eksenel derinlik ve kesme hizına bağll olarak moment grafiği.

Moment değişimleri eksenel derinliklere göre değerlendirildiğinde artan derinlik ile birlikte momentin arttığ gözlenmektedir. $\mathrm{Bu}$ beklenilen bir durum olup çalışmanın olumlu olduğunu göstermektedir. Meydana gelen en düşük moment değeri $180 \mathrm{~m} /$ dak kesme hızında $4 \mathrm{~mm}$ eksenel derinlikte $1,25036 \mathrm{Nm}$, en yüksek moment değeri ise $200 \mathrm{~m} / \mathrm{dak}$ kesme hızında $8 \mathrm{~mm}$ derinlikte $6,48052 \mathrm{Nm}$ olarak tespit edilmiştir. Parametreler arasında en yüksek değişim \%126 ile 
$200 \mathrm{~m} /$ dakk kesme hızında $6 \mathrm{~mm}$ derinlikten $8 \mathrm{~mm}$ derinliğe artışta oluşmuştur. En düşük değişim ise \%19 ile yine $200 \mathrm{~m} / \mathrm{dak}$ kesme hızında $4 \mathrm{~mm}$ derinlikten $8 \mathrm{~mm}$ derinliğe artışta oluşmuştur.

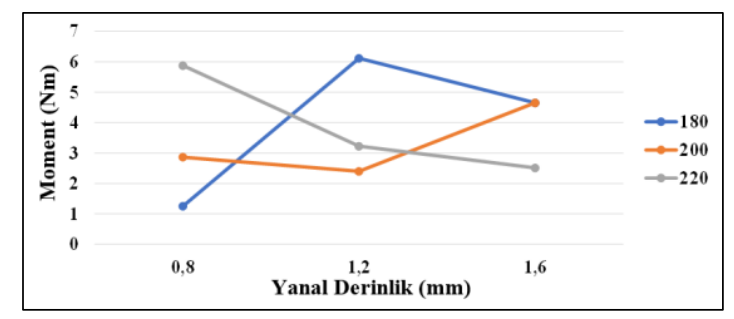

Şekil 7. Yanal derinlik ve kesme hızına bağll olarak moment grafiği.

Yanal derinliğin kesme hızı ile birlikte momente etkisinde en düşük moment değeri $0,8 \mathrm{~mm}$ yanal derinlik ve $180 \mathrm{~m} / \mathrm{dak}$ kesme hızında, en yüksek değer ise yine $180 \mathrm{~m} /$ dak kesme hızında ve $1,2 \mathrm{~mm}$ yanal derinlikte meydana gelmiştir. Aralarında \%389'luk bir değişim meydana gelmiş olup en yüksek değişim de bu parametrelerde olmuştur. En düşük değişim ise \%19 olarak $200 \mathrm{~m} /$ dak kesme hızında $0,8 \mathrm{~mm}$ 'den 1,2 mm yanal derinliğe artışta meydana gelmiştir.

\subsection{Sıcaklık Değerlendirmesi}

Talaşlı imalat işlemlerinde kesici takımın iş parçası malzemesini kestiği bölgede meydana gelen sıcaklık, kesici takımın geometrisine, malzemenin özellikleri, kesme parametrelerine ve işleme koşullarına (soğurtmalı ve kuru işleme) göre değişim göstererek dağılım sergilemektedir. Kesme sırasında oluşan aşırı sıcaklık kesici takımda aşınmaya ve akabinde malzemenin istenilen verimlilikte işlenmesine engel olmaktadır. $\mathrm{Bu}$ nedenle kesme parametrelerinin sıcaklığa olan etkisi değerlendirilmiştir. Şekil 8'de kesici takım üzerinde meydana gelen sıcaklık dağılımları (maksimum ve minimum sıcaklık değerlerine göre yapılmıştır), Şekil 9, Şekil 10 ve Şekil 11 'de ise kesme parametrelerinin sicaklık oluşumu üzerine etkileri grafiksel olarak verilmiştir.

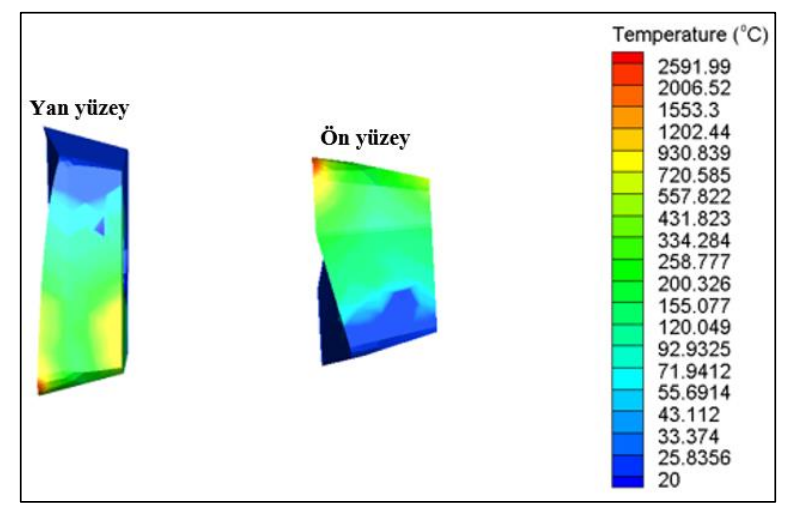

Şekil 8. Kesici takımda meydana gelen sıcaklık dă̆ılımı.

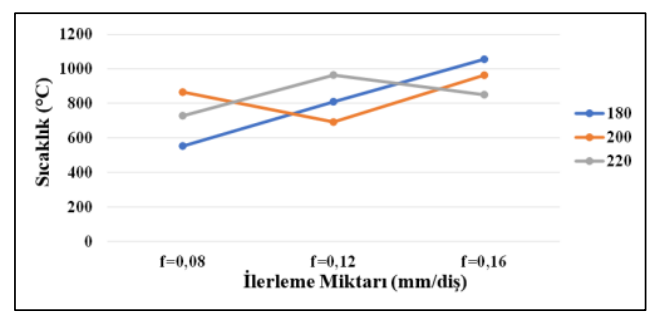

Şekil 11. Illerleme miktarı ve kesme hızına bağlı olarak sıcaklık değişim grafiği.
İlerleme miktarının artmasıyla genel anlamda sicaklık miktarlarında artış gözlenmektedir. En düşük sıcaklık değeri $0,05 \mathrm{~mm} /$ diş ilerleme miktarı ve $180 \mathrm{~m} /$ dak kesme hızında oluşmuştur. En yüksek sıcaklık ise yine $180 \mathrm{~m} / \mathrm{dak}$ kesme hızında ve $0,16 \mathrm{~mm} /$ diş ilerleme miktarında oluşmuştur. En yüksek ve düşük sıcaklık değerleri arasında \%91'lik değişim tespit edilmiştir. Birbirlerini takip eden kesme parametreleri arasında en yüksek ve en düşük sıcaklık değişim oranları sirasıyla \%47 (180 m/dak kesme hizında 0,08 mm'den 0,12 mm ilerleme miktarına artışta) ve \%13 (220 m/dak kesme hızında 0,12 mm'den 0,16 $\mathrm{mm}$ ilerleme miktarına artışta) olarak belirlenmiştir.

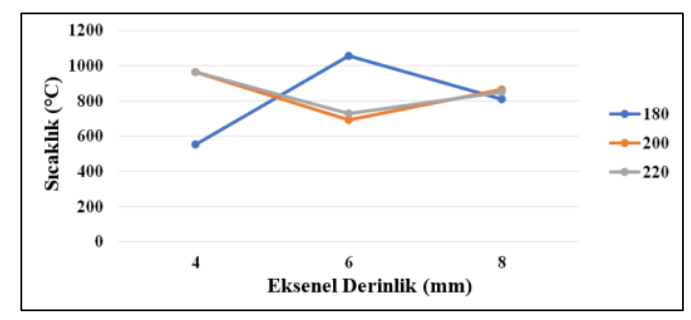

Şekil 12. Eksenel derinlik ve kesme hızına bağll olarak sıcaklık değişim grafiği.

En yüksek sıcaklık $180 \mathrm{~m} /$ dak kesme hızı ve $6 \mathrm{~mm}$ eksenel derinlikte, en düşük sıcaklık ise $180 \mathrm{~m} /$ dak kesme hızı ve $4 \mathrm{~mm}$ eksenel derinlikte meydana gelmiştir. Parametreler arasındaki en yüksek değişim yine $180 \mathrm{~m} /$ dak kesme hızında 4 mm'den $6 \mathrm{~mm}$ eksenel derinliğe artışta oluşmuştur. En düşük değişim ise 220 $\mathrm{m} /$ dak kesme hızında $6 \mathrm{~mm}$ derinlikten $8 \mathrm{~mm}$ derinliğe artışta meydana gelmiştir.

Şekil 13'te yer alan yanal derinlik etkisinin incelenmesi sonucunda meydana gelen sicaklık en yüksek $180 \mathrm{~m} /$ dak kesme hızı 1,6 mm yanal derinlikte ve en düşük sıcaklık ise yine 180 $\mathrm{m} /$ dak kesme hızında $0,8 \mathrm{~mm}$ yanal derinlikte oluşmuştur. Yanal derinliğe göre en yüksek ve düşük değişim oranları ise sırasıyla $\% 39(200 \mathrm{~m} /$ dakk kesme hızında $0,8 \mathrm{~mm}$ yanal derinlikten 1,2 mm yanal derinliğe artışta) ve \%11 (200 m/dak kesme hızında 1,2 mm yanal derinlikte 1,6 mm yanal derinliğe artışta) olarak belirlenmiştir.

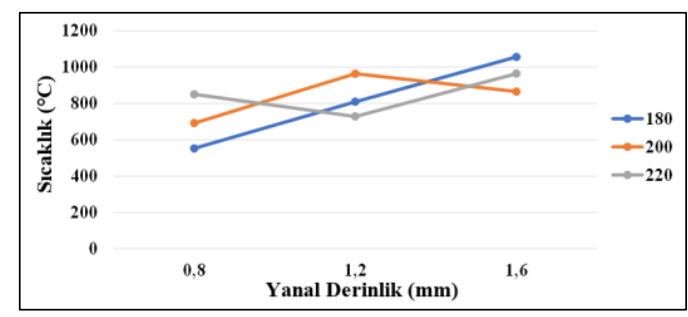

Şekil 13. Yanal derinlik ve kesme hızına bağlı sıcaklık değişim grafiği.

Grafiklerden de anlaşılacağı üzere sıcaklık üzerinde ilerleme miktarının ve yanal derinliğin etkisinin en fazla olduğu gözlenmektedir. Elde edilen sonuçlara göre derinlik ve ilerleme miktarına bağlı olarak sıcaklığın artması talaş kaldırma sırasında birim zamanda artan talaş hacmine atfedilebilir. Bunun nedeni artan talaş hacmi ile plastik deformasyon miktarında ve kesici takım-iş parçası malzemesi arasındaki sürtünmenin artması olarak düşünülmektedir. Ayrıca elde edilen sonuçlar doğrultusunda frezeleme işlemi için sıcaklık dağılımlarının sonlu elemanlar yöntemi ile belirlenebileceği söylenebilir. 


\section{Sonuç}

Çalışmada sonlu elemanlar yöntemi ile yapı çeliğinin frezelenebilirliği kesme kuvvetleri, moment ve sıcaklıklar bakımından incelenmiş̧ir. Yapılan simülasyon çalışmaları sonucunda elde edilen bulgular aşağıda özetlenerek verilmiştir.

Genel anlamda ilerleme miktarının ve kesme derinliklerinin artmasıyla kesme kuvvetlerinde, momentlerde ve sıcaklıklarda artışın meydana geldiği belirlenmiştir.

Kesme hızının artması ile kesme kuvvetlerinde bir süre artış daha sonra azalış, yani dalgalanmalar meydana gelmiştir. Aynı şekilde oluşan sıcaklıklarda da dalgalanmalar oluşmuştur.

Simülasyon sonuçlarında ilerleme yönüne göre oluşan en düşük kesme kuvveti 252,57 N olarak $180 \mathrm{~m} /$ dak kesme hızında, $0,8 \mathrm{~mm}$ yanal derinlikte, $4 \mathrm{~mm}$ eksenel derinlikte ve 0,08 $\mathrm{mm} /$ diş ilerleme miktarında oluşmuştur. En düşük moment değeri $(1,25036 \mathrm{Nm})$ ve sicaklık değeri $(552,193)$ de kesme kuvvetinin en düşük parametrelerinde meydana gelmiştir.

Sonlu elemanlar yöntemi ile frezeleme işleminde işleme parametrelerinin işlenebilirlik çıktılarının tahmini için kullanılabilir olduğu sonucuna ulaşılmıştır.

Sonlu elemanlar yönteminde farklı kesici takımlarla bu parametrelere göre talaş oluşumu gibi işlem çıktısının analizi yapılabilir.

Farklı sonlu elemanlar programları kullanılarak meydana gelen işlem çıktıları karşılaştırılabilir.

\section{Teşekkür}

Bu çalışma Selçuk Üniversitesi Bilimsel Araştırma Projeleri Birimi tarafindan Doktora Tez projesi olarak desteklenmiştir. Proje Numarası: 20111014. Desteklerinden dolayı teşekkür ederiz.

\section{Kaynakça}

Binali, R. (2017). Sıcak iş takım çeliğinin (TOOLOX 44) işlenebilirliğinin incelenmesi. Karabük Üniversitesi Fen Bİlimleri Enstitüsü.

Cadoni, E., \& Forni, D. (2019). Mechanical behaviour of a veryhigh strength steel (S960QL) under extreme conditions of high strain rates and elevated temperatures. Fire Safety Journal, 1-14.

Ceretti, E., Lazzaroni, C., Menegardo, L., \& Altan, T. (2000). Turning simulations using a three-dimensional FEM code. Journal of Materials Processing Technology, 98(1), 99-103.

Chinchanikar, S., \& Choudhury, S. K. (2013). Effect of work material hardness and cutting parameters on performance of coated carbide tool when turning hardened steel An optimization approach Measurement. Measurement, 46(4), 1572-1584.

Gao, X., Li, H., Liu, Q., Zou, P., \& Liu, F. (2011). Simulation of stainless steel drilling mechanism based on Deform-3D. Advanced Materials Research, 160-162, 1685-1690.

Gök, K., Türkes, E., Neseli, S., Saglam, H., \& Gök, A. (2013). The validation as experimental and numerical of the values of thrust force and torque in drilling process. Journal of Engineering Science and Technology Review, 6(3), 93-99.
Gökçe, H., Yavuz, M., Gökçe, H., \& Şeker, U. (2017). Orjinal matkap geometrisinde delme performansinın sonlu elemanlar yöntemi ile doğrulanması. Gazi Mühendislik Bilimleri Dergisi, 3(1), 27-34.

Günay, M., Korkmaz, M. E., \& Yaşar, N. (2017). Finite element modeling of tool stresses on ceramic tools in hard turning. MECHANIKA, 23(3), 432-440.

Korkmaz, M. E., Meral, T., \& Günay, M. (2018). AISI 420 Martenzitik Paslanmaz Çeliğin Delinebilirliğinin Sonlu Elemanlar Yöntemiyle Analizi. Gazi Mühendislik Bilimleri Dergisi, 4(3), 223-229.

Kurt, A., Yalçin, B., \& Yilmaz, N. (2015). The cutting tool stresses in finish turning of hardened steel with mixed ceramic tool. International Journal of Advanced Manufacturing Technology, 80, 315-325.

Küçüktürk, G. (2013). Modeling and analyzing the effects of experimentally determined torque and thrust force on cutting tool according to drilling parameters. Proceedings of the Institution of Mechanical Engineers, Part B: Journal of Engineering Manufacture, 227(1), 84-95.

Özçelik, B., \& Bağc1, E. (2006). Experimental and numerical studies on the determination of twist drill temperature in dry drilling: A new approach. Materials and Design, 27, 920927.

Özel, T. (2009). Computational modelling of 3D turning: Influence of edge micro-geometry on forces, stresses, friction and tool wear in PCBN tooling. Journal of Materials Processing Technology, 209(11), 5167-5177.

SSAB. (2021, $08 \quad$ 25). www.ssab.com.tr. https://www.ssab.com.tr/products/brands/strenx/products/str enx-960-e-f adresinden alınd 1

Tekaüt, İ. (2008). Takım Tezgâhlarındaki Kesici Takım Titreşimin Yüzey Pürüzlülüğüne Etkisi, Yüksek Lisans Tezi. Gazi Üniversitesi Fen Bilimleri Enstitüsü.

Yan, H., Hua, J., \& Shivpuri, R. (2007). Flow stress of AISI H13 die steel in hard machining. Materials and Design, 28(1), 272-277.

Yang, Y., \& Sun, J. (2009). Finite element modelling and simulating of drilling of titanium alloy. nf. and Comp. Sci, ICIC '09. Second Int Conf. 4, 178.

Yardımeden, A., \& Turan, A. (2015). AISI 1040 çeliğin tornalamasinda kesme parametrelerinin kesme kuvvetine etkisi. Dicle Üniversitesi Mühendislik Fakültesi Müühendislik Dergisi, 6(1), 51-59. 